\title{
Oficina educativa para o trabalho em equipe interprofissional: relato de estratégia didática
}

\author{
Jaqueline Silva, Valeria Leonello, Heloise Agreli
}

\section{Resumo}

O ensino do trabalho em equipe por meio da educação interprofissional em saúde (EIP) é fundamental para propiciar a construção de competências para a colaboração. A EIP envolve o aprendizado interativo de estudantes diferentes áreas profissionais com a finalidade de estabelecer a colaboração (Reeves et al, 2016). Os conceitos apresentados foram aplicados em uma oficina educativa, estratégia pedagógica que possibilita a interação e reflexão por meio da construção coletiva de um produto concreto. Esse relato se refere a um construção de um boneco representando um homem, vivência que propicia aos estudantes a oportunidade de reflexão sobre a experiência de interação interprofissional. A estratégia foi baseada no referencial de Educação Crítica de Paulo Freire, pautado na aprendizagem de adultos que enfatiza a participação, o diálogo e a transformação como elementos fundamentais de qualquer processo educativo. Relatar uma experiência de ensino para trabalho em equipe inteprofissional em cursos de graduação da área da saúde. O planejamento da oficina levou em conta o contexto em que foram realizadas, os participantes (estudantes) e os recursos disponíveis. A oficina tem sido realizada em uma universidade pública estadual e uma federal do Estado de São Paulo em disciplinas curriculares formais, optativas interprofissionais e da Graduação e Pós- Graduação. Essas iniciativas já envolveram cerca de 200 estudantes desde 2015 dos cursos de Enfermagem, Medicina, Psicologia, Gerontologia, Odontologia, Educação Física, Biotecnologia, Terapia Ocupacional, Nutrição e Fisioterapia. A oficina foi realizada em salas de aula, com cadeiras e mesas móveis, que possibilitaram a formação e o trabalho em três grupos. Os materiais necessários foram: duas cartolinas, duas colas, duas tesouras, duas réguas, uma caixa de caneta hidrocor ponta grossa (12 cores), uma caixa de giz de cera (12 cores), dois grampeadores, um rolo de barbante, dois rolos de fita crepe. A realização da oficina tem uma duração média de três horas, sendo 30 minutos para o aquecimento, uma hora para a construção da atividade e uma hora e trinta minutos para a discussão e síntese final. No aquecimento da oficina o grupo de docentes, apresenta e propõe a estratégia aos estudantes. A finalidade é sensibilizá-los para o trabalho em equipe, interprofissionalidade, colaboração e cuidado integral. A oficina torna-se uma referência para o desenvolvimento das disciplinas em que ela ocorre, pelo fato dos estudantes e docentes retomarem a vivência sempre que são abordados os referidos temas. A experiência das autoras mostra que não é necessária a apresentação prévia dos conteúdos e conceitos, para que o grupo possa se expressar livremente e de acordo com suas vivências, promovendo a reflexão a partir da ação. Estratégia didática: a construção interdependente de um boneco A turma de estudantes é subdividida em três grupos que recebem um protocolo das peças que precisam produzir para a construção do boneco de um homem: rosto, cabelos, nariz, olhos, sombrancelhas, orelhas, boca, chapéu, tronco, braços, relógio, mãos, quadril, pernas e sapatos. As orientações possuem detalhes sobre as medidas e cores de cada peça mencionada para garantir a proporcionalidade do boneco na montagem. Essa é a primeira fase da atividade, na qual os grupos são orientados a fazer cada uma sua atividade. Os materiais são comuns aos três e colocados sobre uma mesa pelo facilitador. Cada grupo tem 40 minutos para a confecção de sete peças para o boneco e, posteriormente, em 20 minutos realizam a montagem final do boneco reunindo os pedaços produzidos por todas as equipes. Após a construção das peças, os grupos recebem uma nova instrucão: elas terão que montar "uma parte" do boneco, com os materiais que receberem dos demais grupos Ao final, os estudantes são convidados a montar o boneco, unindo as partes e peças construídas. O produto final é um boneco homem que se torna o mascote da turma no semestre, ao qual geralmente é atribuído 
ISSN 2179-6750

um nome. Com a finalização do boneco inicia-se o debrifing da tarefa cumprida e o facilitador anota as percepções gerais no quadro da sala de aula. Os estudantes são convidados a compartilhar sua opinião sobre o produto final e experiência vivenciada no qual o primeiro aspecto que lhes chama a atenção são as assimetrias perceptíveis visualmente no boneco. Referem que apesar do resultado assimétrico o objetivo da tarefa foi cumprido e consideram a importância de compartilharem as medidas das peças entre os grupos durante sua confecção, afim de garantir a simetria do boneco construído coletivamente. O reconhecimento da interdependência entre os membros da equipe inteprofissional propicia o desenvolvimento de valores necessários para a colaboração como o respeito, o mútuo reconhecimento, a troca de saberes, e a comunicação (D’Amour et al., 2008). A percepção dos estudantes sobre a necessidade de estabelecer colaboração entre as equipes está relacionada com o cotidiano dos serviços, pois os profissionais das equipes comprometidas com o cuidado colaboram sempre que há necessidades de saúde complexas apresentadas pelos usuários, com o intuito de refletir conjuntamente sobre as melhores intervenções vislumbrando resultados qualificados (Agreli et al., 2017). A assimetria do boneco pode ser relacionada com resultados obtidos por intervenções em saúde pautadas no modelo biomédico hegemônico que possuem sua relevância e certa efetividade, mas pelo fato de se desenvolverem, com ênfase na remissão de sinais e sintomas por meio de intervenções especificas e muitas vezes isoladas de cada professional reduzem o êxito das ações profissionais devido a fragmentação e falta de articulação das decisões (Frenk et al., 2010). Outros atributos do trabalho em equipe mencionados pelos participantes são objetivos comuns, comunicação, capacidade de negociação, necessidade de liderança e coordenação das tarefas, conflitos, flexibilidade para mudanças, criatividade, capacidade de inovação, troca de conhecimentos, reconhecimento das diferentes habilidades e talentos. Os referidos atributos podem ser relacionados com as competências para a colaboração interprofissional desenvolvidas pela Canadian Interprofessional Health Collaborative (CIHC, 2010) prática centrada no usuário, família e comunidade, comunicação interprofissional, dinâmica do trabalho em equipe, resolução de conflitos, clarificação de papéis profissionais e liderança compartilhada. A oficina educativa para o trabalho em equipe interprofissional, com uso de estratégia didática de construção coletiva de um 'boneco' se mostra adequada para sensibilização de educandos para os temas: prática centrada no usuário, família e comunidade, comunicação interprofissional, trabalho em equipe, resolução de conflitos, clarificação de papéis profissionais e liderança compartilhada. A oficina permite ainda a reflexão acerca da comunicação para o sucesso de atividades que envolvam a interdependência entre profissionais, como é o caso da prática colaborativa.

Descritores: Educação, Educação Interprofissional, Educação em saúde 